\title{
PENGARUH PEMBERIAN EKSTRAK ETANOL DAN KLOROFORM DAUN SIRSAK TERHADAP KOLESTEROL TOTAL DAN TRIGLISERIDA PADA TIKUS YANG DIINDUKSI ALOKSAN
}

\section{THE INFLUENCE OF ETHANOL AND CHOLOFORM EXTRACT OF SOURSOUP LEAVES OF TOTAL CHOLESTEROL AND TRIGLYCERIDE IN ALLOXAN INDUCED RATS}

\author{
Deni Firmansyah $^{1}$, Moch. Saiful Bachri ${ }^{2}$, Nurkhasanah ${ }^{2}$ \\ ${ }^{1}$ Akademi Farmasi Muhammadiyah Cirebon \\ Jl. Cideng Indah no. 3 Cirebon \\ ${ }^{2}$ Fakultas Farmasi Universitas Ahmad Dahlan, Yogyakarta \\ Jln. Prof. Dr. Soepomo Yogyakarta, Telp. (0274) 379418 \\ Email:deni_king3@yahoo.com
}

Submitted: 07-12-2015

Reviewed: 19-02-2016 Accepted: 03-05-2016

\begin{abstract}
ABSTRAK
Tanaman sirsak (Annona muricata) adalah tanaman obat yang sering digunakan untuk pengobatan berbagai macam penyakit, termasuk diabetes mellitus. Penelitian ini bertujuan untuk mengetahui pengaruh pemberian ekstrak etanol dan ekstrak kloroform dari daun sirsak terhadap nilai kolesterol total dan trigliserida. Penelitian ini dilakukan pada 9 kelompok tikus wistar jantan yang terdiri dari 5 ekor tikus per kelompok, terdiri dari kontrol normal, kontrol aloksan, kontrol glibenklamid dosis $10 \mathrm{mg} / \mathrm{Kg} \mathrm{BB}$, kelompok ekstrak etanol daun sirsak dosis $50 \mathrm{mg} / \mathrm{Kg} \mathrm{BB} ; 100$ $\mathrm{mg} / \mathrm{Kg} \mathrm{BB} ; 200 \mathrm{mg} / \mathrm{Kg} \mathrm{BB}$, dan kelompok ekstrak kloroform daun sirsak dosis $50 \mathrm{mg} / \mathrm{Kg} \mathrm{BB} ; 100$ $\mathrm{mg} / \mathrm{Kg} \mathrm{BB} ; 250 \mathrm{mg} / \mathrm{Kg}$ BB . Pengujian dilakukan selama 2 minggu. Hasil penelitian ini menunjukkan bahwa ekstrak etanol daun sirsak dosis $200 \mathrm{mg} / \mathrm{Kg} \mathrm{BB}$ memiliki aktivitas dalam menurunkan kadar glukosa darah lebih baik dibandingkan kelompok lain. Hasil Pemberian ekstrak etanol dan ekstrak kloroform semua dosis kecuali pada kelompok perlakuan ekstrak etanol dosis $200 \mathrm{mg} / \mathrm{Kg}$ BB dan 100 $\mathrm{mg} / \mathrm{Kg} \mathrm{BB}$ setelah selama 14 hari terlihat kadar trigliserida yang masih tinggi dan penurunan nilai total cholesterol (TC) terlihat pada semua kelompok. Ekstrak etanol dosis $200 \mathrm{mg} / \mathrm{Kg} \mathrm{BB}$ memiliki potensi yang baik untuk menurunkan kadar trigliserida dan kolesterol total. Kesimpulan dari penelitian ini adalah ekstrak etanol daun sirsak mempunyai aktivitas anti diabetes mellitus dan menurunkan kolesterol.
\end{abstract}

Kata kunci: Annona muricata, anti diabetes, aloksan, trigliserida, kolesterol total

\begin{abstract}
Annona muricata plant is a medicinal plant using by research and drug for human healthy including diabetes mellitus. This research aimed to determine the effect of ethanol extract and chloroform extract of the sirsak leaf as antidiabetes mellitus. This research was conducted in 9 groups of male Wistar rats consisting of 5 rats per group, consisting of normal control, alloxan control, glibenclamide control dose of $10 \mathrm{mg} / \mathrm{Kg} \mathrm{BW}$, group of ethanol extract sirsak leaf dose of $50 \mathrm{mg} / \mathrm{Kg}$ $\mathrm{BW} ; 100 \mathrm{mg} / \mathrm{Kg} \mathrm{BW} ; 200 \mathrm{mg} / \mathrm{Kg} \mathrm{BW}$, and group of chloroform extract sirsak leaf dose of $50 \mathrm{mg} / \mathrm{kg}$ BW; $100 \mathrm{mg} / \mathrm{Kg} \mathrm{BW} ; 250 \mathrm{mg} / \mathrm{Kg} \mathrm{BW}$. Tests carried out for 2 weeks. It also conducted assays of total flavonoids and histopathological tests of pancreatic $\beta$ cells. Results of this research showed that the ethanol extract of sirsak leaves dose of $200 \mathrm{mg} / \mathrm{Kg} \mathrm{BW}$ has activity in decreasing blood glucose levels better than any other group. Results of the ethanol extract and chloroform extract all doses except the
\end{abstract}


ethanol extract treatment group dose of $200 \mathrm{mg} / \mathrm{kg} \mathrm{BW}$ and $100 \mathrm{mg} / \mathrm{kg} \mathrm{BW}$ after a 14-day look is still high triglyceride levels and decrease in total cholesterol (TC) were seen in all group Ethanol extract dose of $200 \mathrm{mg} / \mathrm{kgBW}$ has a good potential to reduce levels of triglycerides and total cholesterol. The conclusion of this research is the ethanol extract of sirsak leaf have activity antidiabetic mellitusand decreased total cholesterol.

Keywords: Annona muricata, antidiabetic, alloxan, triglyseride, total cholesterol

\section{PENDAHULUAN}

Diabetes mellitus (DM) adalah salah satu yang paling umum menyerang gangguan metabolik endokrin pada abad ke-21, dan ancaman besar bagi kesehatan di seluruh dunia. Pengamatan eksperimental dan klinis banyak telah mengindikasikan bahwa hiperglikemia dapat secara langsung atau tidak langsung berkontribusi terhadap pembentukan radikal bebas berlebihan (Ceriello, 2003). Berbagai penelitian epidemiologi menunjukkan adanya kecendurungan peningkatan angka insiden dan prevalensi DM dari tahun ke tahun. Di Indonesia, WHO memprediksi kenaikan jumlah pasien dari 8,4 juta pada tahun 2000 menjadi sekitar 21,3 juta pada tahun 2030. Diabetes mellitus merupakan penyakit kronis yang mempunyai ciri dengan adanya abnormalitas metabolisme karbohidrat, lipid, protein dan berkaitan dengan defisiensi insulin (Suryawanshi et al., 2006). Pada penyakit DM, lebih dari $95 \%$ penderita DM merupakan penderita diabetes melitus tipe 2 (DMT2) serta tipe ini paling banyak menjadi permasalahan. Gejala diabetes melitus tipe 2 antara lain disfungsi pankreas dan peningkatan kadar lipid, asam lemak serta kolesterol dalam darah (lipemia) (Wadkar, et al., 2008). Umumnya kadar trigliserida dan kolesterol akan meningkat pada penderita diabetes. Menurut Vijayaraghavan (2010) dalam penelitiannya, walaupun kadar LDL kolesterol tergolong normal, resistensi insulin memicu beberapa perubahan pada metabolisme lipid dan komposisi lipoprotein yang memicu LDL kolesterol dan lipoprotein lainnya lebih patogenik dibanding dengan yang tidak diabetes. Hubungan peningkatan kadar trigliserida pada orang diabetes terkait dengan resistensi insulin. Pada penderita diabetes terjadinya defisiensi insulin menyebabkan hormon glukagon bekerja merangsang aktivitas lipase sensitif hormon di jaringan adiposa. Aktivitas ini menyebabkan peningkatan lipolisis dan bertambahnya pasokan asam lemak bebas ke hati. Sehingga sintesis VLDL-trigliserida oleh hati juga meningkat. Salah satu fungsi insulin meningkatkan aktivitas lipoprotein lipase sehingga jumlah asam lemak yang berasal dari lipoprotein digunakan untuk sel. Akan tetapi pada penderita diabetes, aktifitas dari enzim lipoprotein sintase terhambat sehingga terjadi peningkatan lipolisis VLDL-trigliserida yang menyebabkan meningkatnya asam lemak bebas dalam plasma darah dan kadar lemak dalam jaringan adipose menurun (Marks et al.,1996).

Annona muricata adalah tanaman dari family Annonaceae. Tanaman obat yang telah digunakan sebagai obat alami untuk berbagai penyakit, salah satunya adalah untuk pengobatan penyakit diabetes melitus (Adeyemi, et al, 2009). Kulit kayu, akar dan daun Annona muricata telah dilaporkan untuk digunakan sebagai anti-diabetes. Oleh karena itu penelitian ini dirancang untuk menginformasikan efek ekstrak etanol dan ekstrak kloroform dari daun Annona muricata pada kontrol glikemik pada tikus diabetes yang di induksi aloksan. Dimana kemungkinan senyawa aktif sebagai agen antidiabetes mellitus pada pelarut etanol adalah senyawa polar seperti flavonoid dan senyawa aktif yang larut pada pelarut kloroform adalah senyawa non polar, sehingga hasil dari penelitian ini dapat membantu dalam pemilihan terapi diabetes mellitus yang lebih baik lagi.

\section{METODE PENELITIAN Alat dan Bahan}

Alat yang digunakan adalah Neraca analitik, alat maserasi, mesin penggiling, ayakan mesh 40 dan mesh 30, corong pisah, freeze drier Labconcoseri freezone 6 plus, rotavapor, suntik per oral, suntik injeksi, On Call Plus Blood Glucose Test Strips, glucometer, Spektrofotometer UV-1800 Shimadzu, sentrifuge, dan alat gelas yang lazim digunakan. Bahan yang digunakan adalah daun sirsak (Annona muricata), etanol 70\%, chloroform, tikus jantan galur Wistar yang berumur 2-2,5 bulan dengan berat 190-210 gram, pelet tikus, formalin 10\%, glibenklamid, aloksan, $\mathrm{Na} \mathrm{CMC}, \mathrm{NaCl} 0,9 \%$, alumunium klorida $10 \%$, natrium asetat. 


\section{Jalannya Penelitian \\ Preparasi sampel dan uji anti diabetes}

Daun sirsak (Annona muricata) yang diperoleh kemudian dilakukan sortasi. Daun sirsak yang kering diserbuk dan diayak dengan mesh 30 dan 40. Ekstrak dibuat dengan cara maserasi dengan menggunakan etanol $70 \%$ dan kloroform. Semua maserat dikumpulkan dan diuapkan dengan rotary evaporator hingga diperoleh ekstrak kental, ditimbang dan dicatat randemen yang diperoleh. KLT dilakukan terhadap ekstrak etanol dan ekstrak kloroform. Fase diam berupa silika gel $254 \mathrm{~nm}$, Butanol: Asetat Glasial : Air $=4: 1: 5$ dengan pembanding kuersetin. Kadar flavonoid total dengan menggunakan spektrofotometer UV -1800 Shimadzu dimana penentuan kadar flavonoid total sesuai dengan metode Chang et al (2002).

\section{Adaptasi tikus}

Tikus Wistar dewasa umur 2-2,5 bulan dengan berat 190-250 gram, jenis kelamin jantan dipelihara dalam kandang kawat dengan suhu ruangan dan mengalami siklus 12 jam siang-malam. Hewan diberi makan dengan pelet dan diberi minum secukupnya.

Tikus dipuasakan semalam dengan cara intraperitoneal dengan menggunakan aloksan yang dibuat baru. Aloksan dengan dosis $160 \mathrm{mg} / \mathrm{kg}$ berat badan dilarutkan dalam normal saline sampai larut. Hari ke empat setelah penyuntikan aloksan, diambil darah melalui vena di ekor kemudian diukur serum glukosa darah puasa bila kadar glukosa darah 200-300 mg/dl maka tikus tersebut bisa dikategorikan sebagai tikus yang diabetes (Dhandapani, 2002; Chougale et al., 2007). Aloksan merupakan senyawa penginduksi diabetes yang umum digunakan selain streptozotocin.

Uji dilakukan pada 9 kelompok uji yang tiap kelompok terdiri dari 5 tikus. Kelompok terdiri atas kontrol normal, kontrol aloksan, kontrol glibenklamid, kelompok ekstrak etanol dosis $50 \mathrm{mg} / \mathrm{Kg}$; $100 \mathrm{mg} / \mathrm{Kg} ; 200 \mathrm{mg} / \mathrm{Kg}$, kelompok ekstrak kloroform dosis $50 \mathrm{mg} / \mathrm{Kg} ; 100 \mathrm{mg} / \mathrm{Kg} ; 200 \mathrm{mg} / \mathrm{Kg}$ dimana perlakuan dilakukan selama 2 minggu.

\section{Pengukuran glukosa darah}

Uji kadar glukosa dilakukan pada awal sebelum induksi aloksan, sesudah induksi aloksan, minggu ke-1 dan minggu ke-2 untuk melihat perbandingannya. Pengujian dilakukan dengan glukometer (On Call Plus Blood Glucose Test Strips). Pada hari ke-14 tikus kontrol glibenklamid, kontrol sakit, normal, dan kelompok ekstrak etanol dan ekstrak kloroform dikorbankan dengan cara dibius total dengan menggunakan kloroform yang dihirup.

\section{Pengambilan serum untuk uji total kolesterol dan trigliserida}

Darah diambil dari sinus orbitalis pada kondisi tikus yang dibuat pingsan (Li et al, 2006) setelah 16 jam puasa, dan dipindahkan ke tabung sentrifus yang telah disterilkan pada suhu kamar. Sampel darah disentrifugasi selama 10 menit pada 4.000 putaran untuk mendapatkan serum. Serum disimpan dalam freezer pada $0^{\circ} \mathrm{C}$ untuk analisis Total Kolesterol (TC) dan Trigliserida (TG) dengan menggunakan kit komersial (Adeyemi, et al, 2009).

\section{Analisis Statistik}

Hasil pengujian kemudian dianalisis dengan menggunakan uji SPSS, post hoc test dan Mann Whitney digunakan untuk membandingkann masing-masing individu. Nilai signifikan diterima bila $\mathrm{P}<0,05$. Semua hasil ditunjukan sebagai nilai rata-rata $\pm \mathrm{SD}$.

\section{HASIL DAN PEMBAHASAN \\ Uji kadar flavonoid total}

Penentuan kadar flavonoid total dengan menggunakan spektrofotometri UV-Vis. Sebagai standar digunakan kuersetin, suatu senyawa penciri flavonoid yang umum digunakan dan kuersetin merupakan zat aktif kelas flavonoid yang secara biologis amat kuat. Dari hasil perhitungan bahwa persentase kadar flavonoid total dari ekstrak etanol adalah $12,5 \%$ dan persentase kadar flavonoid total dari ekstrak kloroform adalah 5,06 \%. Flavonoid mengandung sistem aromatik yang terkonjugasi oleh karena itu menunjukan pita serapan yang kuat pada daerah ultraviolet dan tampak. Penentuan kadar 
flavonoid dengan menggunakan metoda Chang et al (2002), dimana penambahan pereaksi geser $\mathrm{AlCl}_{3}$ menyebabkan terjadinya pergeseran batokromik yang memungkinkan menunjukkan adanya gugus o-di $\mathrm{OH}$ pada cincin A. Sedangkan penambahan pereaksi geser NaOAc akan menimbulkan pergeseran batokromik yang menunjukkan adanya gugus hidroksi $(\mathrm{OH})$ pada posisi $\mathrm{C}-7$.

Uji efek antidiabetes mellitus ekstrak etanol dan ekstrak kloroform daun sirsak terhadap penurunan kadar glukosa darah

Tabel I. menunjukan data glukosa darah tikus sebelum dan sesudah induksi aloksan. Dari data terlihat bahwa setelah pemberian aloksan selama 4 hari, glukosa darah pada tikus yang diinduksi mengalami peningkatan. Sebelum dilakukan induksi dengan aloksan, tingkat glukosa darah puasa tidak berbeda secara signifikan $(\mathrm{p}<0,05)$ antara delapan kelompok hewan percobaan. Pada 24 jam setelah pemberian aloksan, tingkat glukosa darah secara signifikan $(\mathrm{p}<0,05)$ lebih tinggi pada hewan kelompok ekstrak etanol $50 \mathrm{mg} / \mathrm{Kg}$ BB dan kelompok kontrol negatif dimana menunjukkan kadar glukosa darah $600 \mathrm{mg} / \mathrm{dL}$. Peningkatan kadar glukosa pada tikus yang melebihi kadar $200 \mathrm{mg} / \mathrm{dL}$ dikategorikan sebagai tikus diabetes.

Tabel I. Rata-rata \pm SD Kadar Glukosa Darah Pada Tikus Jantan Yang Diinduksi Aloksan Pada Tiap-Tiap Kelompok

$\begin{array}{lllll}\text { KELOMPOK } & \text { SEBELUM INDUKSI } & \text { Hari ke-4 } & \text { MINGGU } 1 & \text { MINGGU } 2\end{array}$

\begin{tabular}{|c|c|c|c|c|}
\hline NORMAL & - & $127,6 \pm 9,83^{\#}$ & $105,5 \pm 3,41^{\#}$ & $95 \pm 9,59^{\#}$ \\
\hline KONTROL & $102.25 \pm 2,06$ & $600 \pm 0^{*}$ & $565,4 \pm 28,31 *$ & $574,8 \pm 21,47 *$ \\
\hline GLIBENKLAMID & $108,5 \pm 9,84$ & $382 \pm 57,51{ }^{* \#}$ & $205,25 \pm 115,79^{\#}$ & $135,25 \pm 13,69^{* \#}$ \\
\hline EE 200 & $104 \pm 1,82$ & $386,6 \pm 195,18^{*}$ & $216 \pm 94,08 *^{\#}$ & $214 \pm 85,14^{* \#}$ \\
\hline EE 100 & $94 \pm 1,82^{\#}$ & $538,25 \pm 71,36^{*}$ & $345,4 \pm 168,47 *^{* \#}$ & $488,2 \pm 153,09^{*}$ \\
\hline EE 50 & $88,75 \pm 8,99^{\#}$ & $600 \pm 0 *$ & $600 \pm 0 * \#$ & $600 \pm 0 *$ \\
\hline EK 200 & $97,25 \pm 14,15$ & $275 \pm 25^{* \#}$ & $551,75 \pm 55,72^{*}$ & $600 \pm 0^{*}$ \\
\hline EK 100 & $107,25 \pm 3,5$ & $556 \pm 50,91 *$ & $600 \pm 0 *^{\#}$ & $564,5 \pm 34,97 *$ \\
\hline EK 50 & $92,5 \pm 6,45^{\#}$ & $575 \pm 28,87^{*}$ & $600 \pm 0$ *\# & $545,67 \pm 1,52 *^{\#}$ \\
\hline
\end{tabular}

$* \mathrm{p}<0,05$ berbeda signifikan dibandingkan kelompok normal \# $\mathrm{p}<0,05$ berbeda signifikan dibandingkan kelompok sakit.

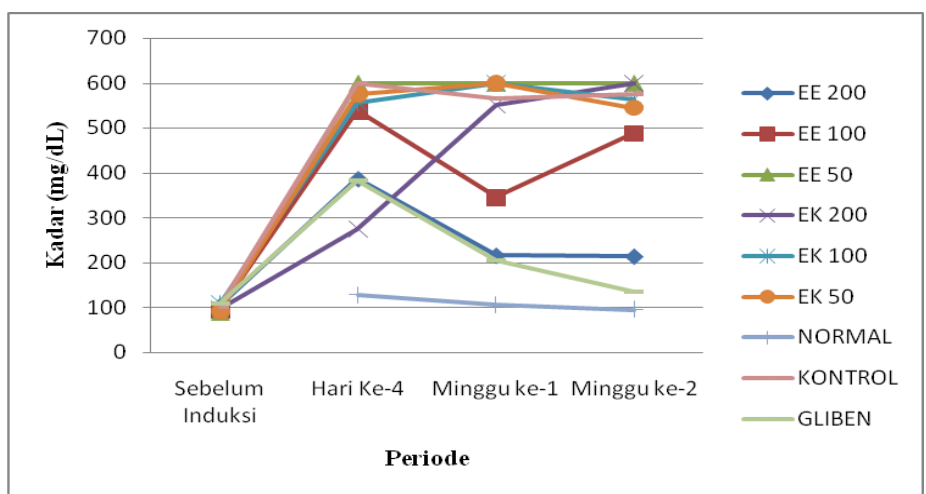

Gambar 1. Grafik Kadar Glukosa Rata-Rata dari Masing-masing Kelompok

Keterangan :

EE 200 : Ekstrak Etanol Dosis $200 \mathrm{mg} / \mathrm{Kg} \mathrm{BB}$

EE 100 : Ekstrak Etanol Dosis $100 \mathrm{mg} / \mathrm{Kg} \mathrm{BB}$

EE 50 : Ekstrak Etanol Dosis $50 \mathrm{mg} / \mathrm{Kg} \mathrm{BB}$

EK 200 : Ekstrak Kloroform Dosis 200 mg/Kg BB 
EK 100 : Ekstrak Kloroform Dosis $100 \mathrm{mg} / \mathrm{Kg} \mathrm{BB}$

EK 50 : Ekstrak Kloroform Dosis $50 \mathrm{mg} / \mathrm{Kg} \mathrm{BB}$

KONTROL : Kontrol Negatif, Kelompok yang induksi aloksan dosis $160 \mathrm{Kg} / \mathrm{BB}$ dengan kadar glukosa darah $>200 \mathrm{mg} / \mathrm{dL}$

GLIBENKLAMID : Kontrol Positif Glibenklamide dosis $10 \mathrm{mg} / \mathrm{Kg}$ BB

NORMAL : Kelompok tanpa pemberian aloksan, glibenklamid, ekstrak etanol dan ekstrak kloroform

Penurunan Kadar glukosa mengalami ketidakstabilan yang terjadi pada minggu pertama dan minggu kedua dimana pada minggu pertama terjadi penurunan kadar glukosa tapi setelah minggu kedua mengalami peningkatan kadar glukosa kembali dapat terlihat dari Tabel I dan Gambar 1. Penurunan kadar glukosa yang stabil hanya terlihat pada ekstrak etanol dosis $200 \mathrm{mg} / \mathrm{Kg} \mathrm{BB}$.

Data diuji homogenitas dengan analisis anova dan menunjukan bahwa data tidak terdistribusi homogen. Data diuji normalitas menggunakan analisis one-sample Kolmogorov-Smirnov menunjukan bahwa data tiap kelompok terdistribusi normal kecuali pada kelompok setelah induksi dimana datanya tidak normal. Untuk melihat perbedaan yang signifikan dari masing-masing kelompok perlakuan dapat dianalisis secara non parametrik dengan menggunakan uji Mann-Whitney. Nilai dikatakan berbeda bermakna bila nilai signifikasi $\mathrm{p}<0,05$.

Glukosa darah antar kelompok sebelum induksi tidak terdapat perbedaan yang bermakna. Ini mencerminkan bahwa tikus yang digunakan pada awal sebelum induksi merupakan tikus yang sehat. Kadar glukosa awal tikus kelompok normal tidak dicek karena tikus tidak ikut diinduksi dengan aloksan. Setelah hari ke-4 kadar glukosa darah dicek kembali untuk memastikan bahwa tikus telah diabetes dan siap untuk diberi perlakuan. Kelompok normal pada minggu kedua terlihat ada perbedaan yang bermakna terhadap semua kelompok, hal ini menunjukan bahwa semua kelompok termasuk glibenklamid pada minggu kedua belum dapat merubah kadar glukosa tikus menjadi normal seperti tikus yang sehat. Kelompok yang paling menunjukan perbedaan yang signifikan terhadap kelompok kontrol adalah kelompok glibenklamid dan kelompok ekstrak etanol dosis $200 \mathrm{mg} / \mathrm{KgBB}$, diikuti dengan kelompok ekstrak kloroform dosis $50 \mathrm{mg} / \mathrm{KgBB}$. Sedangkan semua kelompok berbeda bermakna terhadap kelompok glibenklamid $(\mathrm{p}<0,05)$, kecuali kelompok ekstrak etanol dosis 200 $\mathrm{mg} / \mathrm{Kg}$ BB tidak berbeda bermakna dengan kelompok glibenklamid ( $>00,05$ ). Hal ini menunjukkan bahwa ekstrak etanol dosis $200 \mathrm{mg} / \mathrm{Kg}$ BB dapat menurunkan kadar glukosa darah sebaik dengan kelompok glibenklamid. Data yang menunjukan bahwa kadar gula dapat menurun secara konsisten dari sesusah induksi, pada minggu pertama perlakuan dan minggu kedua perlakuan dan lebih baik dibanding kelompok perlakuan lain adalah kelompok ekstrak etanol dosis $200 \mathrm{mg} / \mathrm{KgBB}$.

Meningkatnya kadar glukosa darah pada pemberian aloksan dapat disebabkan oleh dua proses yaitu terbentuknya radikal bebas dan kerusakan permeabilitas membran sel sehingga terjadi kerusakan sel beta pankreas yang berfungsi menghasilkan insulin (Yusrika, 2009). Cunha et al., (2008) telah melaporkan bahwa beberapa flavonoid menunjukkan aktivitas hipoglikemik pada tikus normal dan tikus yg di beri aloksan. Ekstrak etanol daun sirsak mengurangi kadar glukosa darah pada tikus diabetes dengan mekanisme yang dikaitkan dengan kemampuannya untuk memperbaiki keadaan fisik membran plasma melalui peningkatan tingkat GSH hati, dan menunjukkan bahwa aktivitas antioksidan dari ekstrak etanol daun sirsak yang diberikan melindungi jaringan dari efek peroksidasi lipid.

Pada Gambar 2 kadar trigliserida terlihat tidak berbeda antara kelompok normal, kelompok kontrol dan kelompok glibenklamid. Namun terlihat perbedaan yang signifikan $(p<0,05)$ antara kelompok normal dengan kelompok yang diberi perlakuan ekstrak etanol dosis $50 \mathrm{mg} / \mathrm{Kg} \mathrm{BB}$, ekstrak kloroform dosis $200 \mathrm{mg} / \mathrm{Kg} \mathrm{BB}$, ekstrak kloroform dosis $100 \mathrm{mg} / \mathrm{Kg} \mathrm{BB}$ dan ekstrak kloroform dosis $50 \mathrm{mg} / \mathrm{Kg}$ BB. Sedangkan kadar kolesterol total terlihat tidak berbeda ( $>0,05)$ antara kelompok normal, kelompok kontrol kontrol dan kelompok glibenklamid. Dan terlihat perbedaan yang signifikan $(\mathrm{p}<0,05)$ antara kelompok normal dengan kelompok yang di beri perlakuan ekstrak etanol dosis 100 $\mathrm{mg} / \mathrm{Kg} \mathrm{BB}$.

Hasil uji Mann-Whitney kadar trigliserida memperlihatkan bahwa kelompok perlakuan yang tidak menunjukan perbedaan signifikan $(\mathrm{p}>0,05)$ dengan kelompok normal adalah kelompok perlakuan glibenklamid dan kelompok perlakuan ekstrak etanol dosis $200 \mathrm{mg} / \mathrm{Kg} \mathrm{BB}$, dosis 100 $\mathrm{mg} / \mathrm{Kg} \mathrm{BB}$ dan ekstrak kloroform dosis $50 \mathrm{mg} / \mathrm{Kg}$ BB. Kelompok lainnya menunjukan perbedaan 


\section{Kadar Kolesterol Total dan Trigliserida}

Tabel II. Rata-Rata \pm SD Kadar Kolesterol Total Dan Trigliserida Ekstrak Etanol dan Ekstrak Kloroform Daun Sirsak pada Tikus yang Diinduksi Aloksan pada Hari Ke-14.

\begin{tabular}{lccc}
\hline \multicolumn{1}{c}{ Kelompok } & $\begin{array}{c}\text { Dosis } \\
(\mathbf{m g} / \mathbf{K g ~ B B})\end{array}$ & $\begin{array}{c}\text { Trigliserida } \\
(\mathbf{m g} / \mathbf{d L})\end{array}$ & $\begin{array}{c}\text { Kolesterol Total } \\
(\mathbf{m g} / \mathbf{d L})\end{array}$ \\
\hline NORMAL & - & $73,01 \pm 6,06^{\#}$ & $75,09 \pm 0,46^{\#}$ \\
KONTROL & - & $93,04 \pm 7,99^{*}$ & $66,46 \pm 3,83^{*}$ \\
EE & 50 & $201,59 \pm 7,53^{* \#}$ & $63,84 \pm 5,65^{*}$ \\
EE & 100 & $68,76 \pm 10,22^{\#}$ & $45,46 \pm 8,92^{* \#}$ \\
EE & 200 & $71,71 \pm 2,16^{\#}$ & $44,59 \pm 0,8 *^{* \#}$ \\
EK & 50 & $101,48 \pm 6,96$ & $55,61 \pm 2,48^{* \#}$ \\
EK & 100 & $170,59 \pm 0,4 *^{* \#}$ & $58,05 \pm 1,5 *^{* \#}$ \\
EK & 200 & $138,94 \pm 2,8 *^{* \#}$ & $59,35 \pm 0,8 *^{*}$ \\
GLIBENKLAMID & 10 & $71,55 \pm 19,25$ & $65,59 \pm 1,99^{*}$ \\
\hline
\end{tabular}

* $\mathrm{p}<0,05$ berbeda signifikan dibandingkan kelompok normal , \# $\mathrm{p}<0,05$ berbeda signifikan dibandingkan kelompok kontrol.

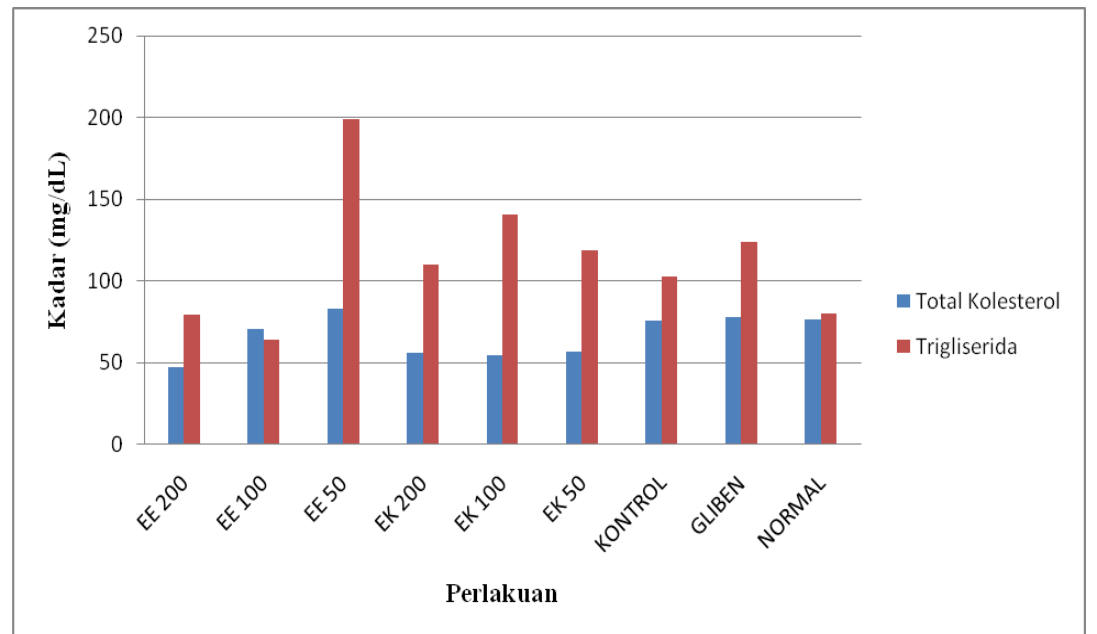

Gambar 2. Grafik Kadar Kolesterol Total dan Trigliserida Rata-Rata hari Ke-14 Ekstrak Etanol dan Ekstrak Kloroform Daun Sirsak pada Tikus Yang Diinduksi Aloksan.

Keterangan :
EE 200 : Ekstrak Etanol Dosis $200 \mathrm{mg} / \mathrm{Kg} \mathrm{BB}$
EE 100 : Ekstrak Etanol Dosis $100 \mathrm{mg} / \mathrm{Kg} \mathrm{BB}$
EE 50 : Ekstrak Etanol Dosis $50 \mathrm{mg} / \mathrm{Kg} \mathrm{BB}$
EK 200 : Ekstrak Kloroform Dosis $200 \mathrm{mg} / \mathrm{Kg} \mathrm{BB}$
EK 100 : Ekstrak Kloroform Dosis $100 \mathrm{mg} / \mathrm{Kg} \mathrm{BB}$
EK 50 : Ekstrak Kloroform Dosis $50 \mathrm{mg} / \mathrm{Kg}$ BB
KONTROL : Kontrol Negatif, Kelompok yang induksi aloksan dosis $160 \mathrm{Kg} / \mathrm{BB}$ dengan kadar glukosa darah $>200 \mathrm{mg} / \mathrm{dL}$
GLIBEN : Kontrol Positif Glibenklamide dosis $10 \mathrm{mg} / \mathrm{Kg} \mathrm{BB}$
NORMAL : Kelompok tanpa pemberian aloksan, glibenklamid, ekstrak etanol dan ekstrak kloroform

Pada Gambar 2 kadar trigliserida terlihat tidak berbeda antara kelompok normal, kelompok kontrol dan kelompok glibenklamid. Namun terlihat perbedaan yang signifikan $(\mathrm{p}<0,05)$ antara 
kelompok normal dengan kelompok yang diberi perlakuan ekstrak etanol dosis $50 \mathrm{mg} / \mathrm{Kg} \mathrm{BB}$, ekstrak kloroform dosis $200 \mathrm{mg} / \mathrm{Kg} \mathrm{BB}$, ekstrak kloroform dosis $100 \mathrm{mg} / \mathrm{Kg} \mathrm{BB}$ dan ekstrak kloroform dosis $50 \mathrm{mg} / \mathrm{Kg}$ BB. Sedangkan kadar kolesterol total terlihat tidak berbeda ( $>0,05)$ antara kelompok normal, kelompok kontrol kontrol dan kelompok glibenklamid. Dan terlihat perbedaan yang signifikan $(\mathrm{p}<0,05)$ antara kelompok normal dengan kelompok yang di beri perlakuan ekstrak etanol dosis 100 $\mathrm{mg} / \mathrm{Kg} \mathrm{BB}$.

Hasil uji Mann-Whitney kadar trigliserida memperlihatkan bahwa kelompok perlakuan yang tidak menunjukan perbedaan signifikan $(p>0,05)$ dengan kelompok normal adalah kelompok perlakuan glibenklamid dan kelompok perlakuan ekstrak etanol dosis $200 \mathrm{mg} / \mathrm{Kg} \mathrm{BB}$, dosis 100 $\mathrm{mg} / \mathrm{Kg} \mathrm{BB}$ dan ekstrak kloroform dosis $50 \mathrm{mg} / \mathrm{Kg}$ BB. Kelompok lainnya menunjukan perbedaan yang signifikan $(\mathrm{p}<0,05)$ terhadap kelompok normal. Hal ini menunjukkan bahwa kelompok ekstrak etanol dosis $200 \mathrm{mg} / \mathrm{Kg}$ BB memiliki potensi yang baik untuk menurunkan kadar trigliserida sebanding dengan kelompok glibenklamid. Pengukuran kadar kolesterol total menunjukan bahwa semua kelompok memiliki perbedaan yang signifikan terhadap kelompok normal. Kelompok glibenklamid dan ekstrak etanol dosis $50 \mathrm{mg} / \mathrm{Kg}$ BB tidak berbeda signifikan $(\mathrm{p}>0,05)$ dengan kelompok kontrol, yang berarti kadar kolesterol total pada kelompok kontrol sudah turun pada hari ke14, sedangkan pada hari ke-14 kelompok yang paling menunjukan perbedaan yang signifikan terhadap kelompok kontrol untuk penurunan kadar glukosa adalah kelompok glibenklamid dan kelompok ekstrak etanol dosis $200 \mathrm{mg} / \mathrm{KgBB}$. Pada penelitian yang dilakukan selama 14 hari dengan pemberian ekstrak etanol dan ekstrak kloroform walaupun dapat menurunkan kadar glukosa darah, kadar trigliserida dan kadar kolesterol total untuk dosis $200 \mathrm{mg} / \mathrm{Kg}$ BB. Hal ini diduga kandungan senyawa aktif senyawa flavonoid dan tanin meningkatkan aktivitas enzim lipoprotein lipase sehingga dapat menurunkan kadar trigliserida dalam plasma (Ririn et. al., 2015).

\section{KESIMPULAN}

Pemberian ekstrak etanol dosis $200 \mathrm{mg} / \mathrm{Kg}$ BB dan dosis $100 \mathrm{mg} / \mathrm{Kg}$ BB selama 7 hari pertama dapat menurunkan kadar glukosa dalam darah. Pemberian ekstrak etanol daun sirsak dosis $200 \mathrm{mg} / \mathrm{Kg}$ BB selama 14 hari dapat menurunkan kadar glukosa darah secara signifikan. Pemberian ekstrak etanol dan ekstrak kloroform semua dosis kecuali pada kelompok perlakuan ekstrak etanol dosis $200 \mathrm{mg} / \mathrm{Kg}$ $\mathrm{BB}$ dan $100 \mathrm{mg} / \mathrm{Kg} \mathrm{BB}$ setelah selama 14 hari terlihat kadar trigliserida yang masih tinggi dan penurunan nilai total cholesterol (TC) terlihat pada semua kelompok. Ekstrak etanol dan ekstrak kloroform daun sirsak (Annona muricata) menurunkan kadar glukosa dan kolesterol, meskipun belum memberikan hasil yang sama dengan glibenklamid.

\section{DAFTAR PUSTAKA}

Adewole S., Ojewole J A O., 2009, Protective Effects of Annona Muricata Linn. (Annonaceae) Leaf Aqueous Extract on Serum Lipid Profiles and Oxidative Stress in Hepatocytes of Streptozotocin-Treated Diabetic Rats. African Journal of Traditional, Complementary and Alternative Medicines (AJTCAM)., 6, 30-41.

Adeyemi O. D., Komolafe O. A., Adewole O. S., Oboutor E. M., Adenowo T. K., 2009, Anti Hyperglycemic Activities of Annona Muricata (Linn). African Journal of Traditional, Complementary and Alternative Medicines (AJTCAM)., 6, 62-69.

Andersen,O.M., and Markham,K.R., 2006, Flavonoids : chemistry, biochemistry, and applications, United State of America CRC Press, Taylor \& Francis Group, 3-13.

Chang, Chia-Chi., Yang, Ming-Hua., Wen, Hwei-Mei., Chern, Jiing-Chuan., 2002, Estimation of Total Flavonoid Content in Propolis by Two Complementary Colorimetric Methods, Jounal of Food and Drug Analysis, Mei, 10., 3, 178-182

Ceriello A., 2003, New insights on oxidative stress and diabetic complications may lead to a "causal" antioxidant therapy. Diabetes Care. 26, 1589-1596.

Chougale, A. D., Panaskar, S. N., Gurao, P. M., Arvindekar, A. U., 2007, Optimization of Alloxan Dose is Essential to Induce Stable Diabetes for Prolonged Period, Asian Journal of Biochemistry, 2 (6), 402-408 
Cunha W.R., G.M. Arantes, D.S. Ferreira, R. Lucarini, M.L.A. Silva, N.A.J.C. Furtado, A.A. da Silva Filho, A.E.M. Crotti, A.R.B. Araújo, 2008, Hypoglicemic effect of Leandra lacunosa in normal and alloxan-induced diabetic rats, Fitoterapia, 79, 356-360

Dhandapani, S., Subramanian, V. R., Rajagopal, S., Namasivayam, N., 2002, Hypolipidemic Effect of Cuminum cyminum L. on Alloxan- Induced Diabetic Rats. Pharmacological Research, Juni., 46, $3,251-255$.

K.A. Wadkar, C.S Magdum, S.S.Patil and N.S.Naikwade., 2008, Anti-diabetic potential and indian medicinal plants. Journal of Herbal Medicine and Toxicology., 2(1), 45-50

Marks, D. B.,Marks, A. D., Smith, C. M., 1996, Biokimia Kedokteran Dasar: Sebuah Pendekatan Klinis. Penerjemah: Brahm U. Pendit, Jakarta, Penerbit EGC, 513-530.

Nugoho A.E., 2006, Hewan Percobaan Diabetes Melitus : Patologi dan Mekanisme Aksi Diabetogenik, 7(4), 378-382

Ririn Lispita Wulandari, Sri Susilowati dan Sucyati Amelya, 2015, Pengaruh Kombinasi Ekstrak Etanol Daun Sirsak Dan Gemfibrozil Terhadap Kadar Trigliserida Dan Hdl Tikus Yang Diinduksi Pakan Tinggi Lemak, Prosiding Seminar Nasional Peluang Herbal Sebagai Alternatif Medicine Tahun 2015, 78-84.

Suryawanshi, N.P., Buthey, A.K., Nagdote, A.A., Manookar, G.S., 2006, Study of Lipid Peroxide and Lipid profile in Diabetes mellitus. Indian J. Biochem, 21 (1),126-130.

Vijayaraghavan,K.,2010, Treatment of dyslipidemia in patients with type 2 Diabetes, 9:144.

Yusrika F.A., 2009, Efek Aloksan Terhadap Kadar Glukosa Darah Tikus Wistar, Fakultas Kedokteran Universitas Diponegoro Semarang, 13-15. 